\title{
Feeding behaviour and daily ration of the spotted flounder Citharus linguatula (Osteichthyes: Pleuronectiformes) in the central Tyrrhenian Sea
}

\author{
PAOLO CARPENTIERI, TIZIANA CANTARELLI, FRANCESCO COLLOCA, \\ ALESSANDRO CRISCOLI and GIANDOMENICO ARDIZZONE
}

Animal and Human Biology Department, University of Rome "La Sapienza", Viale dell’Università 32, 00185 Rome, Italy. E-mail: paolo.carpentieri@uniroma1.it

\begin{abstract}
SUMMARY: Spotted flounder Citharus linguatula (Linnaeus, 1758) is one of the most abundant species within demersal fish assemblages next to the continental shelf (up to $200 \mathrm{~m}$ depth) of the Mediterranean Sea. In spite of the ecological importance of this species in the central Tyrrhenian Sea, many aspects of its biology (e.g. feeding behaviour) are poorly described. In order to analyze how feeding habits are related to the ontogenetic changes in this species, 2636 specimens (between 9 and $26 \mathrm{~cm}$ of total length TL) were collected from November 2000 to January 2002. During ontogenetic development spotted flounder occupied different trophic levels: diet shifted from mysids, predominantly in the smaller spotted flounder $(<11 \mathrm{~cm} \mathrm{TL})$, towards fish in the larger individuals $(>19 \mathrm{~cm} \mathrm{TL})$. Before the transition to the icthyophagous phase, a more generalist foraging behaviour including decapods (Processa sp., Alpheus glaber), molluscs (Turitella sp.) and benthic fish (Lesuerigobius spp., Gobius niger, Callionymus spp., Arnoglossus laterna) dominated the diet. Seasonal analysis of the diet showed an increase in the presence of mysids in summer and autumn, and of decapods in summer and spring. Teleosteans are present throughout the year without significant variations. Daily ration values, computed from the Eggers method, ranged from $1.57 \%$ to $2.83 \%$ wet body weight, showing a negative relationship between reproduction and daily consumption rate.
\end{abstract}

Keywords: spotted flounder, feeding, Mediterranean Sea, ontogenesis, Pleuronectiformes.

RESUMEN: Comportamiento alimenticio y Ración diaria de la Solleta Citharus linguatula (Osteichthyes: PleuRONECTIFormes) En el mar TirReno Central. - La solleta, Citharus linguatula, es una de las especies más abundantes entre las comunidades de peces de la plataforma continental (hasta los $200 \mathrm{~m}$ de profundidad) del Mediterráneo. A pesar de su importancia ecológica en el mar Tirreno central, muchos aspectos de la biología de $C$. linguatula (e.g. alimentación) continúan siendo desconocidos. Con el objetivo de investigar cómo los hábitos alimenticios están relacionados con los cambios ontogénicos en esta especie, se analizaron 2636 individuos, entre 9 y $26 \mathrm{~cm}$ de longitud total (LT), que fueron muestreados entre noviembre de 2000 y enero de 2002. Durante el desarrollo ontogénico C. linguatula ocupa diferentes niveles tróficos: la alimentación varía desde los misidáceos, que son predominantes para las solletas más pequeñas $(<11 \mathrm{~cm}$ LT), hasta los peces, que son la presa más importante para los individuos de mayor talla ( $>19 \mathrm{~cm} \mathrm{LT})$. Antes de llegar a la fase piscívo$\mathrm{ra}$, el régimen alimenticio es más generalista, incluyendo crustáceos decápodos (Processa sp., Alpheus glaber), moluscos (Turitella sp.) y peces bentónicos (Lesueurigobius spp., Gobius niger, Callionymus spp., Arnoglossus laterna). Los análisis estacionales de la dieta muestran un aumento de la presencia de misidáceos en verano y otoño, y un aumento de decápodos en verano y primavera. Los teleósteos están presentes todo el año sin ninguna variación significativa. Las valores de la tasa diaria de alimentación, calculados con el método de Eggers, variaron entre $1.57 \%$ y $2.83 \%$ del peso húmedo individual, con una relación negativa entre la reproducción y el consumo diario.

Palabras clave: solleta, alimentación, Mediterráneo, desarrollo ontogénico, Pleuronectiformes. 


\section{INTRODUCTION}

The spotted flounder Citharus linguatula (Linnaeus, 1758) is a benthic species distributed in the whole Mediterranean basin and along the Atlantic coasts of Portugal, Morocco and Angola (Nielsen, 1986). It generally inhabits sandy and muddy bottoms of the continental shelf up to $200 \mathrm{~m}$ depth. In the Mediterranean basin the species provides an important contribution to commercial landings: it is regularly found at fish markets and is an important by-catch accompanying species for the trawling fleet. Together with Lepidorhombus boscii and Solea vulgaris, it is the most important and abundant resource of the Mediterranean Sea in the group of flatfishes (Sartor et al., 2002). In the Italian part of the Mediterranean it is exploited mainly by a fleet that uses a peculiar kind of trawl, called rapido, and it is caught as an associated species of the target common sole (S. vulgaris) and scallops (Aequipecten opercularis, Chlamys glabra and Pecten jacobaeus).

Most of the available information on spotted flounder comes from studies on distribution and abundance (Jardas, 1984; García-Rodríguez and Esteban, 2000; Sartor et al., 2002), age, growth (Vassilopoulou and Papaconstantinou, 1994; Çakýr et al., 2005) and sexual cycle and reproduction (Sabatés, 1988). However, its feeding habits have been poorly investigated (Planas and Vives, 1956; Redon et al., 1994). Despite the increasing interest in life-cycle and energetic demands (e.g. feeding ecology and daily ration) of the demersal communities, no information is available, at least for the Mediterranean, on the ontogenesis and daily ration of this species. As Wootton (1990) pointed out, the foraging behaviour of all animals in a community is the key feature of the community stability and structure.
The aim of this paper is (1) to provide information on the daily and seasonal feeding behaviour of $C$. linguatula; (2) to analyze its ontogenesis-related diet changes; (3) to produce estimates of its food consumption based on daily ration models.

\section{MATERIAL AND METHODS}

\section{Study area}

Spotted flounder sampling was carried out on the continental shelf of the Tyrrhenian Sea. This area extends down to $120-150 \mathrm{~m}$ depth, covering $15-30 \mathrm{~km}$ of distance from the shoreline (Fig. 1). The sea surface temperature ranges from $12-15^{\circ} \mathrm{C}$ in the winter season to $27-28^{\circ} \mathrm{C}$ in the summer; near the bottom (from a depth of $100 \mathrm{~m}$ down to $200 \mathrm{~m}$ ) temperature is constant around $13^{\circ} \mathrm{C}$.

Most of the fishing area is characterized by sandymuddy bottoms (SFBC-VTC benthic assemblage, Pérès and Picard [1964]) and muddy bottoms (VTC) between 10 and $150 \mathrm{~m}$ depth.

\section{Sampling}

Size-stratified samples were obtained monthly during a ground fish survey on board a commercial rapido trawler. The rapido trawl used is made of an iron frame provided with skids and a toothed bar on its lower side; a wooden plank is fitted to the front of the iron frame to act as a spoiler and keep the gear in contact with the seabed. The net is $4.8 \mathrm{~m}$ long and consists of two portions: the first one connected to the rapido mouth has a stretched mesh size of 24 by $30 \mathrm{~cm}$; the second one is the codend, with a mesh size of $39.9 \mathrm{~cm}$. The

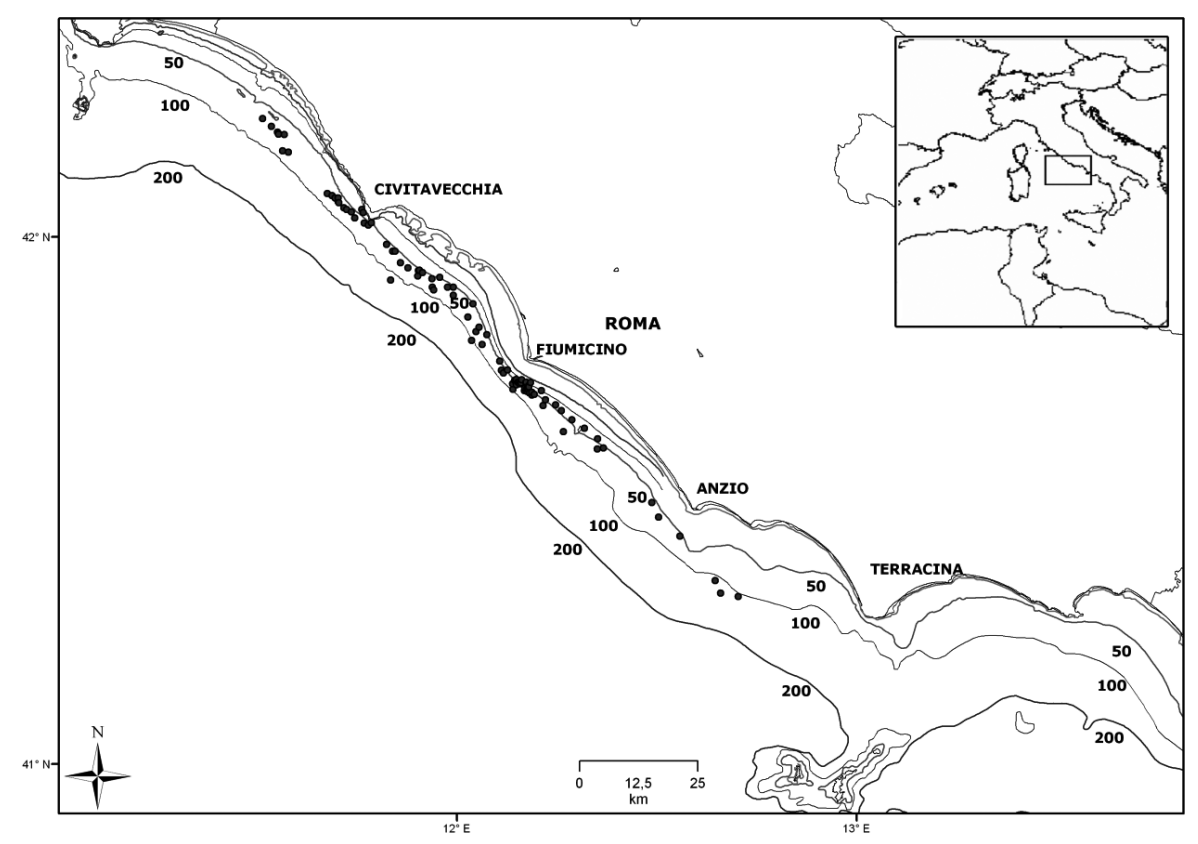

FIG. 1. - Study area. Points represent the trawl stations located on the continental shelf of the central western coasts of Italy. 
lower portion of the net is protected by a reinforced rubber diamond-mesh matting (stretched mesh size $24 * 30 \mathrm{~mm}$ ).

Two rapido trawls are usually towed at a speed of about 5.5-6 knots and each trawl-haul covered a distance of approximately $20 \mathrm{~km}$. The fishing activity is carried out for about 14-16 hours from night (about 01:00) to dusk (about 19:00) without stopping. A total of about 6-8 hauls per fishing day are performed. To standardize the data, the hauls were pooled according to the time of the day into 2-hour time steps.

In order to emphasize the main diet changes in relation to the growth processes, spotted flounder were collected monthly from November 2000 to the end of January 2002. Seasons were defined as follows: samples carried out after 23 September were classified as autumn hauls; after 21 December as winter hauls; after 21 March as spring hauls and after 21 June as summer hauls. Samples were collected at least every 2 hours over a period of about $20 \mathrm{~h}$ to test for a diel cycle.

Samples of $C$. linguatula were frozen immediately after catch and stored at $-20^{\circ} \mathrm{C}$ to prevent further digestion of prey. Later, fish were brought back to the laboratory where individual total body weight (BW, measured to the nearest $0.01 \mathrm{~g}$ ), and total length (TL, rounded to the next half centimetre) were measured. Stomachs were removed and preserved in $70 \%$ ethanol solution, and prey were identified to the lowest possible taxonomic level, counted, and weighed (to the nearest $0.01 \mathrm{mg}$ ). When the state of digestion was more advanced, prey were sorted and grouped into unidentified Osteichthyes, Crustacea or Mollusca. The collected data of stomach contents were classified with respect to the time of the day, fish length and season.

Sex and maturity stages were analyzed macroscopically. The maturity scale for partial spawner fish was used to classify the stage of maturation (Holden and Raitt, 1974).

\section{Data analysis}

The size at which $50 \%$ of the fish were mature $\left(\mathrm{TL}_{50}\right)$ was calculated using the following logistic function (Sparre et al., 1989):

$$
\left.\mathrm{P}_{T L}=1 /\left(1+\mathrm{e}^{\left(S_{1}-S_{2} T L\right.}{ }_{50}\right)\right)
$$

where $\mathrm{P}_{T L}$ is the percentage of mature individuals for length classes; $\mathrm{S}_{1}$ and $\mathrm{S}_{2}$ are constants and $\mathrm{TL}_{50}$ is given by $\mathrm{S}_{1} / \mathrm{S}_{2}$.

Size-related dietary variations were investigated by dividing all the specimens into $2 \mathrm{~cm}$ length-classes, with the exception of the largest individuals $(>21 \mathrm{~cm}$ TL) all included into a single length-class.

Hierarchical cluster analysis and non-metric multidimensional scaling (NMDS), based on Bray-Curtis similarity and on the IRI\%, were used for classification and ordination of spotted-flounder size classes (Clarke and Warwick, 1994).
The contribution of each food item to the diet, for the different length classes and for the size dietary groups individuated by the NMDS and Cluster Analysis was evaluated using the index of relative importance (IRI, Pinkas et al., 1971) as modified by Hacunda (1981). This index, expressed as:

$$
\text { IRI } \%=\text { IRI }- \text { - IIRI } * 100
$$

incorporates the percentage by number $(\mathrm{N} \%)$, wet weight (W\%) and frequency of occurrence (F\%) (Hyslop, 1980).

The diel feeding periodicity was investigated by means of stomach fullness index, expressed as the percentage ratio of the weight of a fish's stomach contents to its total body weight $\left(\mathrm{FI} \%=\mathrm{W}_{\mathrm{s}} / \mathrm{W}_{\mathrm{t}}^{*} 100\right)$ (Tudela and Palomera, 1995).

One-way ANOVA was used to test for differences in stomach fullness (FI\%) between relative fish abundance (expressed as number of individuals per hour $\mathrm{n}^{\mathrm{h}-1}$ ) and day/night hauls, and for differences between seasons and size groups. The differences were considered significant at $\mathrm{P}<0.05$.

The estimate of daily ration, based on the ratio of the percent stomach weight to predator weight $(\% \mathrm{BW})$, was obtained through the model of Eggers (1977):

$$
\left.\mathrm{C}_{24 \mathrm{E}}\right)=\mathrm{F}_{24} \mathrm{R}_{24}
$$

where $\mathrm{F}_{24}$ is the mean stomach fullness index over 24 $\mathrm{h}$ and $\mathrm{R}_{24}^{24}$ is the instantaneous gastric evacuation rate. This model assumes that the feeding periodicity is such that the fullness indexes at the beginning and at the end of a $24 \mathrm{~h}$ period are equal (Boisclair and Marchand, 1993). When this assumption cannot be met and the weight of food in the stomach at the beginning and at the end of the $24 \mathrm{~h}$ cycles are significantly different, Eggers (1979) proposed a corrected model:

$$
\mathrm{C}_{(24 \mathrm{EC})}=\mathrm{C}_{(24 \mathrm{E})}+\left(\mathrm{F}_{\mathrm{t}}=24-\mathrm{F}_{0}=0\right)
$$

where $\mathrm{F}_{\mathrm{t}}=24$ and $\mathrm{F}_{0}=0$ are the values of stomach fullness index at the end and the beginning of the sampling period.

In order to estimate daily ration the instantaneous coefficient of gastric evacuation $R$ must be obtained. Since the instantaneous food evacuation rate of this species had never been evaluated before, the values used here were obtained from temperature-based models ( $R$ ' - Durbin et al., 1983; Worobec, 1984; Macpherson, 1985) and determined from our experimental data set following the $R_{\max }$ procedure (Héroux and Magnan, 1996).

The first model, the most widely accepted in the literature to describe food evacuation in most fish species, is probably more appropriate for describing the evacuation of small, relatively easily digested particles from the stomach (Worobec, 1984; Macpherson, 1985). This model assumes $R^{\prime}=0.0175 \mathrm{~T}-0.0442$ for 
TABLE 1. - Number of fish samples and stomach contents collected during the four sampling periods. For each season the value of the stomach fullness (FI), the length range and the mean standard length of the collected samples are reported.

\begin{tabular}{lccccc}
\hline Season & $\begin{array}{c}\text { n. of } \\
\text { fish }\end{array}$ & $\begin{array}{c}\text { n. of } \\
\text { stomachs }\end{array}$ & FI & $\begin{array}{c}\text { length range } \\
(\mathrm{cm})\end{array}$ & $\begin{array}{c}\text { mean length } \\
(\mathrm{cm})\end{array}$ \\
\hline Autumn & 1080 & 589 & 0.55 & $9.5-25$ & 14.4 \\
Summer & 559 & 376 & 0.67 & $10.5-26$ & 15.4 \\
Winter & 505 & 256 & 0.51 & $10-24$ & 14.2 \\
Spring & 492 & 272 & 0.55 & $9-23.5$ & 15.0 \\
\hline
\end{tabular}

fish feeding on polychaetes or small crustaceans, and $R^{\prime}=0.00408 \mathrm{~T}-0.00527$ for fish eating predators, where $\mathrm{T}$ is the temperature in Celsius degrees. Evacuation rate $R^{\prime}$ depends primarily on water temperature and on the prey food type, whereas it is not influenced by food size and by the frequency of feeding (Elliott and Persson, 1978; Durbin et al., 1983; Macpherson, 1985). The constant temperature regime in the study area, around $13^{\circ} \mathrm{C} \pm 0.5$ down to $50-200 \mathrm{~m}$ depth all year around (Ifremer, 1997), means that our estimates of daily ration were probably free of temperature influence.

The $R_{\max }$ procedure assumes the occurrence of a period of non-feeding between two consecutive sampling times. Once the period of non-feeding is identified, the stomach can be assumed to be exclusively egesting and $R_{\max }$ can be computed as the difference between the initial and final stomach contents, following an exponential model:

$$
R_{\max }=\ln \mathrm{FI}_{(\mathrm{T}+1)}-\ln \mathrm{FI}_{(\mathrm{T}) / \mathrm{T}}
$$

where FI ${ }_{(T+1)}$ and FI ${ }_{(T)}$ are the values of the stomach fullness index at the end and at the beginning of the sampling period over a time interval $\mathrm{T}$. In this study the gastric evacuation rate $R_{\max }$ was calculated for two different fish size groups: specimens under $13 \mathrm{~cm}$ TL and specimens over $13 \mathrm{~cm}$ TL (the switch of $13 \mathrm{~cm}$ corresponds to the attainment of maturity size). Thereafter, daily ration values were calculated for the two groups mentioned and for the different seasons.

\section{RESULTS}

\section{Diet in relation with length}

A total of 2636 specimens with a mean standard length of $14.7 \mathrm{~cm}$ (range: 9-26 cm TL) and a mean weight of $26.2 \mathrm{~g}$ (range: 7.5-146 g) were collected for diet analysis (Table 1$)$. Size at maturity $\left(\mathrm{L}_{50}\right)$ was estimated to be $13.3 \mathrm{~cm}(\mathrm{R}=0.95 ; 91.31$ of the variance explained) (Fig. 2); individuals over $18 \mathrm{~cm}$ in length were almost all female $(70 \%)$.

The total number of preys was about 1800 divided into 54 different food items (Table 2). Cluster and NMDS analysis (stress $=0.01$ ), based on the IRI\%, identified three cluster groups below $65 \%$ similarity, separated along a length-size gradient (Fig. 3a). The first group (A) contained fish between 9 and $12.9 \mathrm{~cm}$ TL;

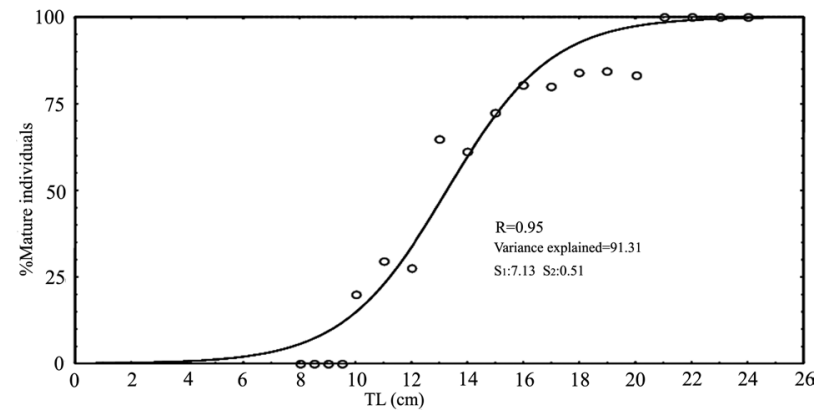

FIG. 2. - Size at maturity of Citharus linguatula. Points represent the percentage of mature individuals for each size class.

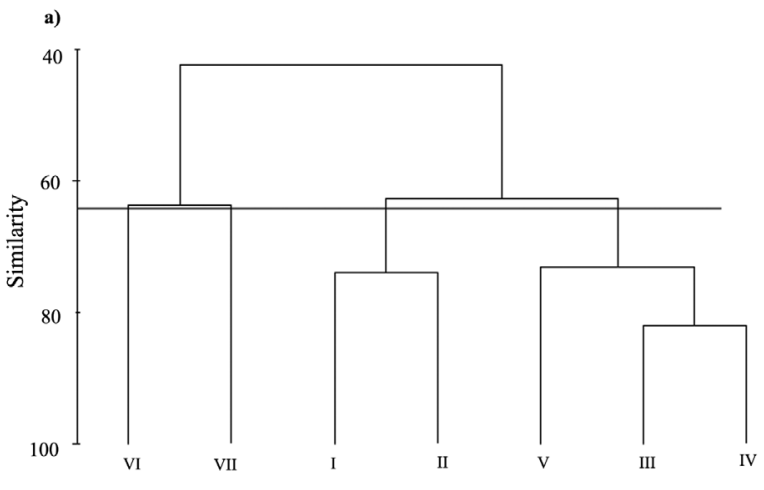

b)

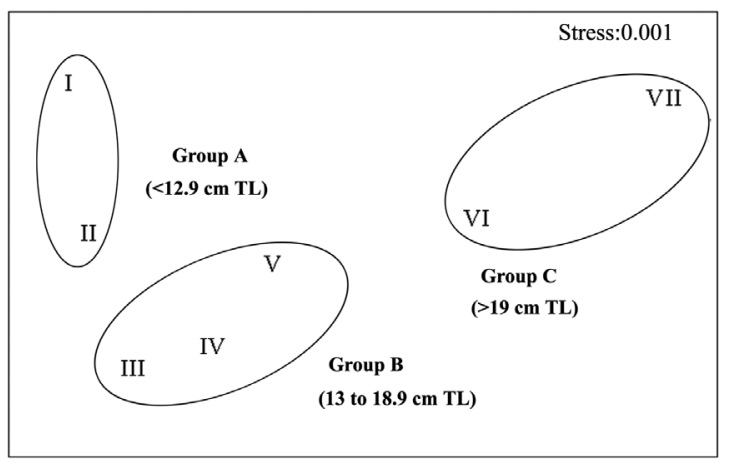

FIG. 3. - Dendogram (a) and NMDS plot (b) based on the IRI\% values, using group-average clustering from Bray-Curtis similarity on diet data.

the second group (B) contained fish between 13 and $18.9 \mathrm{~cm}$ TL; the third group (C) contained specimens longer than $19 \mathrm{~cm}$ TL (Fig. 3b). Mysids (Leptomysis gracilis IRI $=50.2 \%$ ) and small teleosts (Gobiidae IRI= $36.3 \%$ ) dominated the diet of group A. Seasonal dietary patterns of group A, shown as mysids, were important in the stomachs of the spotted flounder throughout the year (Fig. 4), with a significant increase $(\mathrm{P}<0.01)$ in summer $(I R I \%=55.2)$ and autumn $(I R I \%=51.9)$. During both periods, mysids were represented by various species, Gastrosaccus spinifer, Anchialina agilis and Leptomysis apiops, though the greatest contribution of this group to the diet is due to the presence of $L$. gracilis. Teleosteans were the most frequent prey item in winter $(I R I \%=51.7)$ and spring $($ IRI\%= 52.1), but were also an important prey item throughout the year. 
TABLE 2. - Prey items reported as index of relative importance (IRI \%) for the seven size classes. The three size groups (A, B and C) identified by the cluster analysis are indicated.

\begin{tabular}{|c|c|c|c|c|c|c|c|}
\hline \multirow[t]{2}{*}{ Size group } & \multicolumn{2}{|c|}{ A } & \multicolumn{3}{|c|}{ B } & \multicolumn{2}{|c|}{$\mathrm{C}$} \\
\hline & I & II & III & IV & V & VI & VII \\
\hline Length $(\mathrm{cm})$ & $9.0-10.9$ & $11.0-12.9$ & $13.0-14.9$ & $15.0-16.9$ & $17.0-18.9$ & $19.0-20.9$ & $>21.0$ \\
\hline Number of stomachs & 38 & 452 & 1016 & 742 & 297 & & \\
\hline \multicolumn{8}{|l|}{ Mollusca } \\
\hline Allotheutis spp. & & & & 0.001 & & & \\
\hline Hinia incrassata & & & 0.02 & 0.005 & 0.01 & & \\
\hline Parvicardium scabrum & & & 0.001 & & & & \\
\hline Pusillina lineolata & & & 0.001 & & & & \\
\hline Sepietta spp. & & & & 0.01 & & & \\
\hline Sepiolidae n.i. & & & 0.01 & & & & \\
\hline Turritella biplicata & & & 0.03 & 0.03 & 0.02 & & \\
\hline Turritella communis & & & 0.002 & & 0.02 & & \\
\hline Polichaeta & & & & & & & \\
\hline Polichaeta n.i. & & & 0.001 & 0.001 & & 0.15 & \\
\hline \multicolumn{8}{|l|}{ Crustacea } \\
\hline Alpheus glaber & & 0.04 & 13.63 & 22.96 & 27.09 & 22.74 & 16.29 \\
\hline Anapagurus petiti & & & & 0.001 & & & \\
\hline Anchialina agilis & 0.27 & 0.04 & 0.002 & 0.001 & & & \\
\hline Anilocra sp. & & 0.05 & 0.01 & 0.02 & 0.13 & 0.17 & \\
\hline Apseudes latrellei & & & & & 0.01 & & \\
\hline Athanas nitiscens & & & 0.001 & & & & \\
\hline Axiidae n.i. & & & 0.001 & 0.001 & & & \\
\hline Brachicarpus biungulatus & & 0.005 & & 0.001 & & & \\
\hline Callionassa spp. & & & & 0.004 & & & \\
\hline Crangonidae n.i. & 1.10 & 0.38 & 0.16 & 0.13 & 0.01 & & \\
\hline Crustacea n.i. & 2.44 & 0.36 & 0.07 & 0.12 & 0.18 & & \\
\hline Decapoda n.i. & 0.51 & 3.36 & 1.62 & 1.03 & 0.90 & 5.07 & \\
\hline Erytrops spp. & 0.29 & 0.16 & & & & & \\
\hline Gastrosaccus lobatus & & & & 0.001 & & & \\
\hline Gastrosaccus normani & 0.01 & 0.005 & & & 0.01 & & \\
\hline Gastrosaccus spinifer & 0.27 & & 0.002 & 0.01 & & & \\
\hline Gastrosaccus spp. & 2.55 & 0.04 & 0.01 & 0.004 & 0.02 & & \\
\hline Goneplax rhomboides & & 0.01 & & & & & \\
\hline Isopoda n.i. & & 0.04 & 0.01 & 0.001 & & & \\
\hline Leptomysis apiops & 2.50 & & 0.01 & 0.00 & & & \\
\hline Leptomysis gracilis & 49.48 & 49.37 & 18.61 & 12.63 & 4.82 & 1.38 & 1.33 \\
\hline Leptomysis spp. & 15.50 & 0.03 & 0.06 & 0.06 & & & \\
\hline Lophogaster typicus & & 0.02 & 0.02 & 0.001 & & & \\
\hline Misidacea n.i. & & 0.71 & 0.42 & 0.18 & 0.04 & & \\
\hline Natantia n.i. & 0.69 & 1.49 & 0.39 & 0.58 & 0.16 & & \\
\hline Philocheras bispinosus & 1.18 & 1.34 & 0.44 & 0.18 & 0.25 & 0.16 & \\
\hline Philocheras monachantus & & 0.01 & 0.02 & 0.06 & 0.02 & & \\
\hline Philocheras spp. & 1.81 & 2.12 & 0.29 & 0.33 & 0.25 & 0.16 & \\
\hline Processa caniculata & & & 0.02 & 0.01 & 0.62 & & \\
\hline Processa elegantula & & & 0.07 & 0.04 & 0.19 & & \\
\hline Processa spp. & & 0.08 & 0.11 & 0.12 & 0.45 & 0.75 & \\
\hline Squilla mantis & & & 0.001 & 0.01 & & & \\
\hline Upogebia spp. & & & & & 0.01 & & \\
\hline Upogebia tipica & & & 0.012 & & 0.01 & & \\
\hline Teleostea & & & & & & & \\
\hline Arnoglossus laterna & & 0.02 & 0.003 & 0.19 & 0.05 & 5.95 & \\
\hline Callionimus spp. & & 0.05 & 0.002 & 0.03 & & & \\
\hline Cepola macrophtalma & 0.75 & 0.31 & 0.13 & 0.001 & 0.12 & & \\
\hline Deltentosteus quadrimaculatus & 0.76 & 0.82 & 2.86 & 2.36 & 4.47 & 1.25 & 13.54 \\
\hline Engraulis encrasicholus & & & & 0.02 & 0.80 & 1.21 & \\
\hline Gobiidae n.i. & 12.92 & 27.54 & 31.79 & 28.87 & 16.46 & 17.99 & 13.26 \\
\hline Gobius niger & & 0.28 & 0.80 & 1.75 & 0.76 & 10.11 & 6.40 \\
\hline Leuseriogobius spp. & 4.21 & 4.09 & 1.56 & 1.78 & 0.71 & & 1.51 \\
\hline Leuseriogobius sueri & & & 10.34 & 6.10 & 4.16 & 14.54 & 3.67 \\
\hline Serranus hepatus & & & & 0.003 & & & 0.04 \\
\hline Teleostea n.i. & 2.78 & 7.23 & 16.47 & 20.35 & 37.26 & 18.37 & 43.96 \\
\hline
\end{tabular}

Group B showed a more heterogeneous diet, still characterized by a high occurrence of mysids (IRI= $12.7 \%)$, but also with a considerable amount of fish $(\mathrm{IRI}=59 \%)$ and decapods $(\mathrm{IRI}=24.2 \%)$ such as $\mathrm{Al}$ pheus glaber, Processa spp. and Philocheras spp. In this size group (spotted flounder from 13 to $18.9 \mathrm{~cm}$ TL) the presence of mollusc gasteropods (Turritella spp., Hynia incrassata) with lower percentages (IRI= $0.8 \%$ ) was recorded. Dietary patterns (Fig. 4) showed significant differences among seasons $(\mathrm{P}<0.05)$, mainly linked to the high occurrence of decapods in spring $($ IRI\% $=30)$ and mysids in summer $($ IRI\%= 10.5).

The proportion of teleosts increased strongly in Group C, where they accounted for about $80 \%$ in 


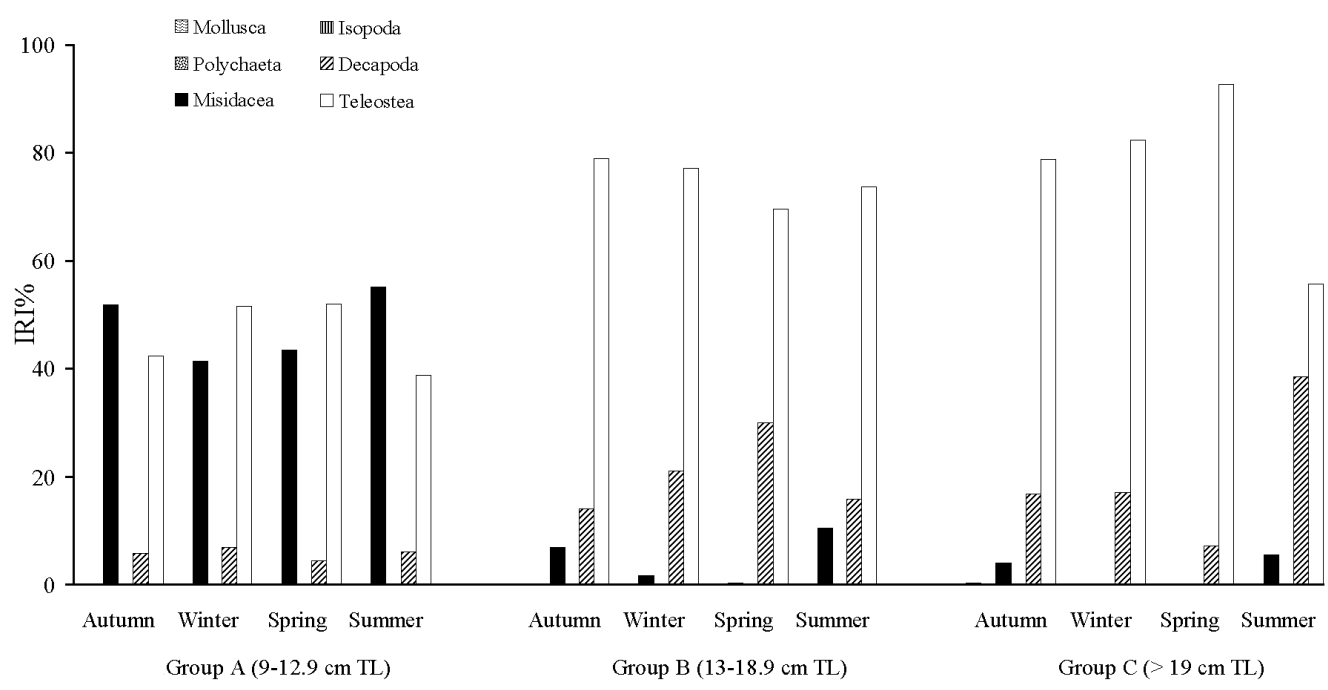

FIG. 4. - Seasonal variation in percentage abundance (IRI\%) of the different prey items for the three spotted flounder size groups identified by the Cluster and NMDS analysis.

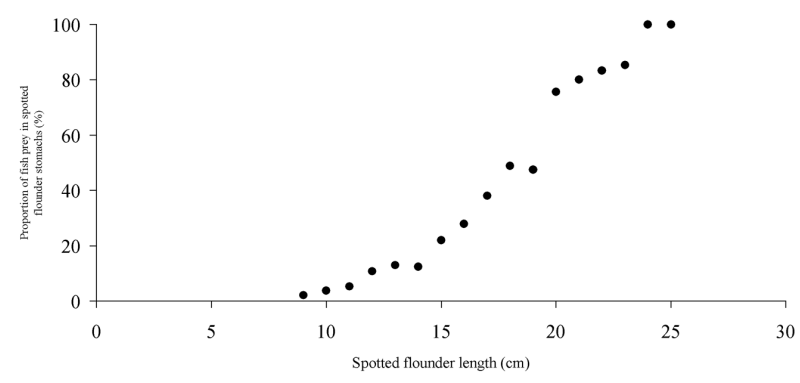

FIG. 5. - Proportion (\%) in number of fish prey occurring in the diet of Citharus linguatula during its growth.

number of the spotted flounder diet (Fig. 5). Teleosts were present throughout the year without significant variations $(\mathrm{P}>0.05)$. The main prey items were Deltentosteus quadrimaculatus (IRI= 3.8\%),
Leuseriogobius suerii $(\mathrm{IRI}=10.9 \%)$ and Gobius niger $($ IRI $=10.5 \%)$, and other Pleuronectiformes such as Arnoglossus laterna $(\mathrm{IRI}=2.7 \%)$. A. glaber $(\mathrm{IRI}=$ $20 \%$ ) was the main prey item among crustaceans decapods. Slight seasonal differences $(\mathrm{P}<0.05)$ in this size group (spotted flounder $>19 \mathrm{~cm} \mathrm{TL}$ ) were mainly linked to the high occurrence of decapods in summer $(\mathrm{IRI} \%=38.5)$.

\section{Diel feeding periodicity and daily ration}

The diel pattern indicated that the presence of spotted flounder was more or less evenly distributed, with no significant relationship $(\mathrm{P}>0.05)$ with either daylight or night hauls. Stomach fullness increased significantly $(\mathrm{P}<0.01)$ by $10: 00$ and continued to rise until 15:00 (Fig. 6). During the early morning, just before sunrise (from 04:00 to 08:00 h) and before sunset (from

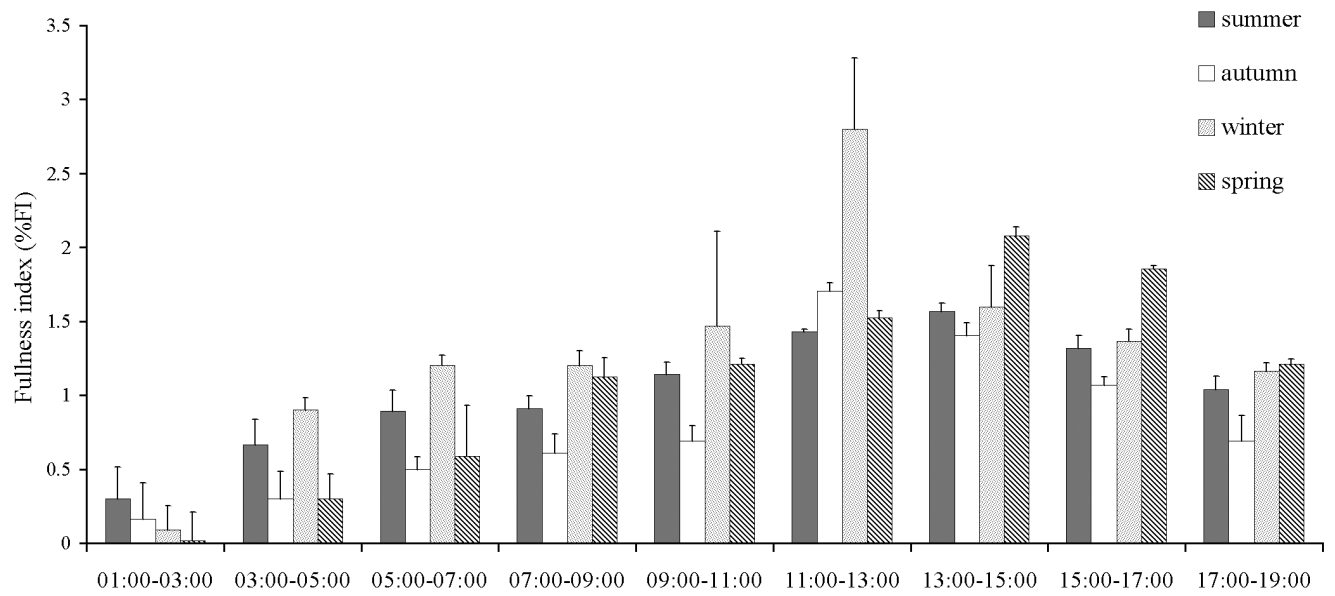

Time of the day (hours)

FIG. 6. - Relationship between time and stomach fullness expressed as \%FI (weight of a fish's stomach contents to its total body weight) in the different sampling periods. Hauls were pooled according to the time of the day into 2-hours time steps. 
TABLE 3. - Daily ration estimates (expressed as percentage of fish body weight - \%BW) obtained with the Eggers (1979) model, both with the direct estimation of the consumption rate $R_{\max }$ and with the instantaneous evacuation rate from bibliographic review $R$ '. SD, standard deviation.

\begin{tabular}{lcccc}
\hline Daily ration & Summer & Spring & Winter & Autumn \\
\hline $\mathrm{R}^{\prime}=0.18(<13 \mathrm{~cm})$ & 2.19 & 2.21 & 2.83 & 2.23 \\
$\mathrm{SD} \pm$ & 0.23 & 0.19 & 0.41 & 0.4 \\
n.stomach & 131 & 110 & 109 & 207 \\
$\mathrm{R}^{\prime}=0.07(>13 \mathrm{~cm})$ & 1.63 & 1.95 & 2.16 & 1.71 \\
$\mathrm{SD} \pm$ & 0.19 & 0.14 & 0.15 & 0.09 \\
n.stomach & 245 & 162 & 147 & 382 \\
$\mathrm{R}_{\max }=0.082(<13 \mathrm{~cm})$ & 1.83 & 2.01 & 2.27 & 1.85 \\
$\mathrm{SD} \pm$ & 0.23 & 0.31 & 0.36 & 0.21 \\
n.stomach & 131 & 110 & 109 & 207 \\
$\mathrm{R}_{\max }=0.064(>13 \mathrm{~cm})$ & 1.57 & 1.93 & 2.12 & 1.68 \\
$\mathrm{SD}_{ \pm}$ & 0.19 & 0.18 & 0.23 & 0.12 \\
n.stomach & 245 & 162 & 147 & 382 \\
\hline
\end{tabular}

17:00 to 19:00) the feeding intensity was observed to be significantly low $(\mathrm{P}<0.01)$.

Mature spotted flounder $(>13 \mathrm{~cm}$ TL) showed a marked daily ration peak in winter $\left(2.16 \% \mathrm{BW} R^{\prime}=0.07\right.$; $\left.2.12 \% \mathrm{BW} R_{\max }=0.064\right)$, while lower values, from 1.57 $\left(R_{\max }=0.064\right)$ to $1.63 \% \mathrm{BW}\left(R^{\prime}=0.07\right)$, were obtained in summer (Table 3). Immature specimens $(<13 \mathrm{~cm}$ TL) also showed a marked daily ration peak in winter $\left(2.83 \% \mathrm{BW} R^{\prime}=0.18 ; 2.27 \% \mathrm{BW} R_{\max }=0.082\right)$, while in the other seasons the values were quite constant: from $1.83 \% \mathrm{BW}$ to $2.01 \% \mathrm{BW}$ with $R_{\max }=0.082$, and from $2.19 \% \mathrm{BW}$ to $2.23 \% \mathrm{BW}$ with $R^{\prime}=0.18$.

\section{DISCUSSION}

In the diet of the spotted flounder 54 different prey items belonging to five major groups were identified. Teleosts, decapods and mysids were the main prey items in all seasons, while molluscs and polychaetes were secondary and complementary preys. In the western Mediterranean, Planas and Vives (1956) and de Juan et al. (2007) found the diet of $C$. linguatula to consist mainly of crustaceans and fishes. Belghyti et al. (1993) reported that mysids appeared to be the main trophic group in the diet of spotted flounder along the Atlantic coasts of Morocco, with teleosts considered as secondary preys, and crustaceans and cephalopods as occasional preys.

During their ontogenetic development spotted flounder occupied different trophic levels. Diet shifted from mysids - the main preys for smaller specimens $(<10.9 \mathrm{~cm} \mathrm{TL})$ - to fish (L. sueri, G. niger, D. quadrimaculatus), which in the larger individuals $(>19 \mathrm{~cm}$ TL) represented almost the entire diet. Specimens between 11 and $19 \mathrm{~cm}$ TL showed a more heterogeneous diet, still characterized by the occurrence of mysids, but also with a considerable amount of fish, decapods and other groups such as polychaetes and gasteropod molluscs. This progressive passage from small preys to larger ones is typical for many Pleuronectiformes (Deniel, 1975; Braber and De Groot, 1973; Lockwood, 1984). Such changes in diet related to size are also connected to morphologic changes associated with the growth of the fish, the increase of the mouth dimensions and probably a greater disposition to move (Wootton, 1990). As reported in the northwestern Mediterranean by de Juan et al. (2007), C. linguatula specimens of different length essentially preyed upon the same species and the only detectable changes were differences in ingested abundance of these preys.

Seasonal analysis of the diet showed an increase in the presence of mysids in summer and autumn, and an increase in the presence of decapods in summer and spring. Teleosteans were present throughout the year without significant variations. Seasonal differences probably reflect temporal variability in prey resources throughout the year. In the western Mediterranean mysid abundance reaches a maximum in late summerautumn (Franqueville, 1971), which coincides with the period of highest consumption by juvenile spotted flounder. The same seasonal trend, linked to the greater frequency index and numerical composition of the mysid L. gracilis in autumn, is confirmed by the study carried out in the Gulf of Valencia by Redon et al. (1994). This result has been reported as the main factor influencing diet composition of generalist and opportunist feeders, such as some Pleuronectiformes species in the Mediterranean (Cabral et al., 2002)In our study, the feeding activity of $C$. linguatula showed a marked daily temporal pattern, with a major peak occurring during daylight and a decline just before sunset. This cycle was found in all samples taken and could be linked to the biology of the species: the spotted flounder normally lives close to the bottom, feeding during daylight on benthic invertebrates and resting during the night (Nielsen, 1986). These results agree with a series of studies carried out on other Pleuronectiformes in which diurnal predator activity was evidenced (De Groot, 1971).

Among other factors, our findings showed that the main shift in the diet might be related to the attainment of sexual maturity. The size-at-maturity $(13.3 \mathrm{~cm}$ TL) was positively associated with a shift in the diet towards bigger preys (i.e. decapods and fish). Under the first maturity size, diet was basically dominated by mysids and small crustaceans. The shift to utilization of large preys might be induced by gonads maturation. As reported by Ross (1978), the change in feeding patterns during growth can be related to particular phases of fish biological cycles. Such an ontogenetic diet shift could indicate that inter- and intraspecific partitioning of energy resources in fish vary with fish size and probably reduce intraspecific competition between immature and mature specimens.

Given the scant information available on the biology and feeding activity of the species studied, it is difficult to compare differences in daily consumption with its habits and metabolic requirements. Comparing our daily ration results with previously published data at similar temperature ranges $\left(13^{\circ} \mathrm{C}\right)$, we noticed that the daily ration values (from $1.57 \% \mathrm{BW}$ to $2.83 \% \mathrm{BW}$ ) 
computed for spotted flounder fall well within the range of estimates obtained by species displaying a similar diet (from $1.4 \% \mathrm{BW}$ to $3.82 \% \mathrm{BW}$; Cartes et al., 2004; Carpentieri et al., 2006). In the Atlantic Ocean for species with diets based on small crustaceans (e.g. Coelorhynchus fasciatus and Pseudopleuronects americanus), Macpherson (1985) obtained a daily ration ranging from 0.55 to $2.15 \% \mathrm{BW}$ whereas Worobec (1984) obtained a daily ration ranging from 1.27 to $3.31 \%$ BW.

Our findings showed a negative relationship between spawning and daily ration. The spawning activity of spotted flounder took place from July to October (in summer around $75 \%$ of the specimens over $13 \mathrm{~cm}$ TL showed ripe gonads), corresponding to the lowest values of daily ration computed for the species (from $1.57 \% \mathrm{BW}$ to $1.63 \% \mathrm{BW}$ ). As already observed in other species, the reduction of food intake during spawning may also have been due to less space available in the body cavity for food, or could have been associated with a change in hormone levels at spawning that might reduce individual foraging (Hoar et al., 1983; Fordham and Trippel, 1999).

The literature suggests that the interaction between feeding and reproduction is both highly variable and complex. Redon et al. (1994) found that the high percentage of empty stomachs was recorded in August to September, and may be related to the reproductive period of the spotted flounder (late summer), during which there is a significant decrease in food intake. In the western Mediterranean, Planas and Vives (1956) determined the spawning season of $C$. linguatula to be summer, corresponding to the maximum vacuity index values recorded in the same period. A similar pattern of decreasing daily ration during the reproduction period was already identified for other species in the Mediterranean (e.g. the synchronous hermaphrodite Serranus hepatus - Carpentieri et al., 2006). In the Atlantic area, there is strong evidence that Atlantic herring (Clupea harengus), four-spot flounder (Hippoglossina oblonga) and red hake (Urophycis chuss) exhibit a "rester" pattern of feeding after spawning during the resting phase (Link and Burnett, 2001).

On the other hand, Mullus barbatus (Ünlüoglu et al., 2002; Carpentieri et al., 2006), Macroramphosus scolopax (Carpentieri et al., 2006) and two Argentinidae, Argentina sphyraena and Glossanodon leioglossus, exhibited an increase in the daily consumption during spawning (Cohen, 1990; Carpentieri et al., 2006). Link and Burnett (2001) demonstrated that the highest levels of daily consumption recorded for the Atlantic mackerel (Scomber scombrus) and silver hake (Merluccius bilinearis) occurred at times of increased sexual activity for both species. As these fish developed gonads and reached maturity, the total stomach contents were significantly higher than during the spent and resting stages (Link and Burnett, 2001).

The determination of the daily ration of C. linguatula presented here, applying the Eggers model, is the first study of its kind carried out for this species in the Mediterranean. The advantage of this model was related to the use of field data with unstressed individuals under a natural feeding regime. Data obtained provided a broad overview of the ecology of the complex scenario present on the Mediterranean platform. The results are generally comparable with the estimated values found for species with similar trophic habits in both the Mediterranean and Atlantic areas. It is plausible that differences in in daily ration estimates could be attributed to varrious factors, such as abundance of prey types, feeding rhythm and digestion rates.

\section{REFERENCES}

Belghyti, D., P. Aguesse and C. Gabrion. - 1993. Ethologie alimentaire de Citharus linguatula et Dicologoglossa cuneata sur les côtes atlantiques du Maroc. Vie Milieu, 43(2-3): 95-108.

Boisclair, D. and F. Marchand. - 1993. The guts to estimate fish daily ration. Can. J. Fish. Aquat. Sci., 50: 1969-1975.

Braber, L. and S.J. De Groot. - 1973. The food of five flatfish species (Pleuronectiformes) in the southern North Sea. Neth. J. Sea Res., 6: 163-172.

Cabral, H.N., M. Lopes and R. Loeper. - 2002. Trophic niche overlap between flatfish in a nursery area on the Portuguese coast. Sci. Mar., 66(3): 293-300.

Çakýr, D.T., B. Bayhan, B. Hoşsucu, A. Ünlüoglu and S. Akalýn. -2005 . Some Parameters of the Population Biology of Spotted Flounder (Citharus linguatula, Linnaeus, 1758) in Edremit Bay (North Aegean Sea). Turk. J. Vet. Anim. Sci., 29: 1013-1018.

Carpentieri, P., F. Colloca, A. Belluscio, A. Criscoli and G.D. Ardizzone. -2006 . Diel feeding periodicity and daily ration of shelf break species. J. Mar. Biol. Assoc. U.K., 86: 853-860.

Cartes, J.E., J. Rey, D. Lloris and L. Gil de Sola. - 2004. Influence of environmental variables on the feeding and diet of European hake (Merluccius merluccius) on the Mediterranean Iberian coasts. J. Mar. Biol. Assoc. U.K., 84: 831-835.

Clarke, K.R. and R.M. Warwick. - 1994. Change in marine communities: an approach to statistical analysis and interpretation. Plymouth Marine Laboratory, Plymouth.

Cohen, D.M. - 1990. Argentinidae. p. 235-238. In J.C. Quero, J.C. Hureau, C. Karrer, A. Post and L. Saldanha (eds.). Check-list of the fishes of the eastern tropical Atlantic (CLOFETA). JNICT, Lisbon; SEI, Paris; and UNESCO, Paris. (1): 235.

De Groot, S.J. - 1971. On the interrelationship between morphology of the alimentary tract, food and feeding behaviour in flatfishes (Pisces: Pleuronectiformes). Neth. J. Sea Res., 5: 121-196.

de Juan, S., J.E. Cartes and M. Demestre. - 2007. Effects of commercial trawling activities in the diet of the flat fish Citharus linguatula (Osteichthyes: Pleuronectiformes) and the starfish Astropecten irregularis (Echinodermata: Asteroidea). J. Exp. Mar. Biol. Ecol., (349): 152-169.

Deniel, C. - 1975. Régimes alimentaires d'Arnoglossus thori Kyle et d'Arnoglossus imperialis Rafinesque (Teleosteens-Botidae) en Baie de Douarnenez. Rev. Trav. Inst. Peches Marit., 39: 105-116.

Durbin, E.G., A.G. Durbin, R.W. Langton and R.E. Bowman. 1983. Stomach contents of silver hake, Merluccius bilinearis, and Atlantic cod, Gadus morhua, and estimation of their daily rations. Fish. Bull. NOAA, 81: 437-454.

Eggers, D.M. - 1977. Factors in interpreting data obtained by diel sampling of fish stomachs. J. Fish. Res. Bd Can., 34: 290-294.

Eggers, D.M. - 1979. Comment on some recent methods for estimating food consumption by fish. J. Fish. Res. Bd Can., 36: 1019-20.

Elliott, J.M. and L. Persson. - 1978. The estimation of daily rates of food consumption for fish. J. Anim. Ecol., 47: 977-991.

Fordham, S.E. and E.A. Trippel. - 1999. Feeding behaviour of cod (Gadus morhua) in relation to spawning. J. Appl. Ichthyol., 15: $1-9$.

Franqueville, C. - 1971. Macroplancton profond (Invertébrés) de la Méditerranée nord-occidentale. Tethys, 3(1): 11-56. 
García-Rodríguez, M. and A. Esteban. - 2000. Contribution to Knowledge of Citharus linguatula (Linnaeus, 1758) (Osteichtyes: Heterosomata) in the Iberian Mediterranean. In: Demersal resources in the Mediterranean, Actes de Colloques IFREMER, 26: $131-140$

Hacunda, J.S. - 1981. Trophic relationships among demersal fishes in a coastal area of the Gulf of Maine. Fish. Bull., 79(4): 775-788.

Heroux, D. and P. Magnan. - 1996. In situ determination of food daily ration in fish: review and field evaluation. Environ. Biol. Fishes, 46: 61-74.

Hoar, W.S., D.J. Randall and E.M. Donaldson. - 1983. Fish physiology, Vol. 9. Reproduction, Part A, Endocrine tissues and hormones. Academic Press, New York.

Holden, M.J. and D.F.S. Raitt. - 1974. Manual of fisheries science. Part 2: Methods of resources investigation and their application. FAO Fish. Tech. Paper, 115, Rev. 1: 1-214.

Hyslop, E.J. - 1980. Stomach contents analysis: a review of methods and their application. J. Fish Biol., 17: 411-429.

Ifremer. - 1997. Mediterranean hydrological atlas (CD rom). IFREMER edition, Brest, France.

Jardas, I. - 1984. Citharus macrolepidotus (Bloch, 1787) (Pisces Pleuronectiformes) nourishment and the length-weight relationship in the Adriatic Sea. Ichthyologia, 16(1-2): 1-4.

Link, J.S. and J. Burnett. - 2001. The relationship between stomach contents and maturity state for major northwest Atlantic fishes: new paradigms? J. Fish Biol., 59: 783-794.

Lockwood, S.J. - 1984. The daily food intake of 0-group plaice (Pleuronectes platessa L.) under natural conditions: changes with size and season. J. Cons., 41(2): 181-193.

Macpherson, E. - 1985. Daily ration and feeding periodicity of some fishes off the coast of Namibia. Mar. Ecol. Prog. Ser., 26: $253-260$

Nielsen, J. - 1986. Citharidae. pp 1286. In: P.J.P. Whitehead, M.L. Bauchot, J.C. Hureau, J. Nielsen and E. Tortonese (eds.), Fish of the North-eastern Atlantic and the Mediterranean. Vol. II, UNESCO, Paris.

Pérès, J.M. and J. Picard. - 1964. Nouveau manuel de bionomie benthique de la mer Méditerranée. Rec. Trav. Stat. Mar. Endoume, 31(47): 1-137.

Pinkas, L., M.S. Oliphant and I.L.K. Iverson. - 1971. Food habits of albacore, bluefin tuna and bonito in California waters. Fish Bull. NOAA, 152: 1-150.
Planas, A. and F. Vives. - 1956. Contribución al estudio de la solleta (Citharus linguatula Gunth) del Mediterraneo occidental. Invest. Pesq., 3: 107-131.

Redon, M.J., M.S. Morte and A. Sanz-Brau. - 1994. Feeding habits of the spotted flounder Citharus linguatula off the eastern coast of Spain. Mar. Biol., 120: 197-201.

Ross, S.T. - 1978. Trophic ontogeny of the leopard sea-robin, Prionotus scitulus (Pisces: Triglidae). Fish. Bull. NOAA, 76(1): 225-234.

Sabatés, A. - 1988. Larval development and spawning of Citharus linguatula (Linnaeus, 1758) in the Western Mediterranean. $J$. Plank. Res., 10: 1131-1140.

Sartor, P., M. Sbrana, N. Ungaro, C.A. Marano, C. Piccinetti and C. Piccinetti Manfrin. - 2002. Distribution and abundance of Citharus linguatula, Lepidorhombus boscii, and Solea vulgaris (Osteichthyes: Pleuronectiformes) in the Mediterranean Sea. Sci. Mar., 66(Suppl. 2): 83-102.

Sparre, P., E. Ursin and S.C. Venema. - 1989. Introduction to tropical fish stock assessment. Part I. Manual. FAO Fish. Tech. Paper, 306(1): 1-337.

Tudela, S. and I. Palomera. - 1995. Diel feeding intensity and daily ration in the anchovy Engraulis encrasicolus in the northwest Mediterranean Sea during the spawning period. Mar. Ecol. Prog. Ser., 129: 55-61.

Ünlüoglu, A., B. Cihangir, M. Kaya, H.L. Benli and T. Katagan. -2002 . Variations in the feeding intensity and diet composition of red mullet (Mullus barbatus) during 24-h period in the summertime in Hisarönü Bay. J. Mar. Biol. Assoc. U.K., 82: $527-528$

Vassilopoulou, V. and C. Papaconstantinou. - 1994. Age, growth and mortality of the spotted flounder (Citharus linguatula Linnaeus, 1758) in the Aegean Sea. Sci. Mar., 58: 261-267.

Wootton, R.J. - 1990. Ecology of teleosts fishes. Chapman and Hall, London.

Worobec, M.N. - 1984. Field estimation of the daily ration of winter flounder, Pseudopleuronectes americanus (Walbaum) in a southern New England Pond. J. Exp. Mar. Biol. Ecol., 77: 183-196.

Scient. ed.: I. Palomera.

Received April 24, 2009. Accepted January 21, 2010.

Published online June 29, 2010. 